\title{
The Determinants of Filariasis Prevention (Elephantiasis Disease) in Lumut Maju Village, Lumut Sub-district, Central Tapanuli Regency
}

\author{
Lasmarida Br Silalahi ${ }^{1}$, Zulfendri ${ }^{2}$, Surya Utama ${ }^{2}$ \\ ${ }^{1}$ Master Student in Universitas Sumatera Utara, Medan, Indonesia \\ ${ }^{2}$ Lecturer in Universitas Sumatera Utara, Medan, Indonesia \\ Email: lasmarida.haniel@gmail.com
}

\begin{abstract}
:
This research deals with the determinants of filariasis prevention (elephantiasis disease) in Lumut Maju Village, Lumut Sub-district, Central Tapanuli Regency. This research is a qualitative type of research with domain analysis. The study was conducted in Lumut Maju Village, Lumut Subdistrict, Central Tapanuli Regency and work units related to the research problem. The results shows that In the context of filariasis prevention, the local government has not coordinated and established networks with relevant SKPDs and in partnership with relevant NGOs and academics. Handling of patients that aims to prevent and limit disability by providing care training to patients and families has not been done to the maximum. Control of risk factors does not work well because the patient is not maximally netted.

Keywords:

disease; filariasis; prevention
\end{abstract}

\section{Introduction}

The environment is very influential on the distribution of filariasis and its transmission chain. The endemic area of Brugia malayi is a swamp forest area, along a river or other body of water that is overgrown with water plants. The physical environment, the biological environment and the social, economic and cultural environment are the causes of filariasis (RI Ministry of Health, 2014).

Based on the explanation Permenkes No. 94 of 2014, that efforts to eradicate filariasis have been carried out since 1975, especially in high-endemic areas of filariasis. In 1997, the World Health Assembly adopted the resolution "Elimination of Lymphatic Filariasis as a Public Health Problem", which was later strengthened in 2000 by the decisions of WHO member countries including Indonesia in the World Health Assembly in Geneva, Switzerland agreed to eliminate elephantiasis to avoid continuing become a public health problem by declaring "The Global Goal of Elimination of Lymphatic Filariasis as a Public Health Problem by the Year 2020". The elimination program is carried out through mass treatment with DEC (Diethyl Carbamazine Citrate) and Albendazol once a year for 5 years in endemic locations and treatment of acute and chronic clinical cases to prevent disability and reduce sufferers (RI Ministry of Health, 2014).

In 2015, the government launched the Elephantiasis Disease Elimination Month program. This program is carried out every October in endemic areas of filariasis through the Administration of Filariasis Mass Prevention Drugs (POPM) with the aim of accelerating the elimination of elephantiasis in 2020 in Indonesia. The implementation of filariasis prevention is carried out by the government and regional governments by involving the participation of the community (RI Ministry of Health Bulletin, 2015). 
The implementation of Elephantiasis Disease Elimination Month program is based on the results of the Finger Blood Survey in endemic and regional areas that have filariasis cases, from 511 districts / cities in Indonesia, 241 districts / cities have been obtained as endemic areas. From the data obtained that of the 241 regencies / cities, 46 regencies / cities have implemented the administration of mass prevention drugs (POPM) filariasis with a commitment of at least five years in the hopes of succeeding in reducing microfilaria in the community to $<1 \%$. The administration of filariasis prevention drugs is given to every person aged two years to 70 years unless they have certain health indications (Seftia, 2017).

Central Tapanuli is a Regency located on the west coast of North Sumatra province and its territory is at $0-1,266 \mathrm{~m}$ above sea level with an area of $6,194.98 \mathrm{~km}^{2}$. The population of Central Tapanuli is 356,918 people, most of whom live in underdeveloped/remote areas of the border. Infectious diseases caused by mosquito vectors (malaria, DHF and filariasis) are still relatively high in Central Tapanuli region due to tropical conditions, where many types of mosquitoes that successfully live and breed (Central Tapanuli Profile, 2017).

Lumut Sub-district is a border area of Central Tapanuli with South Tapanuli Regency, in that area consists of one health service facility in Lumut Health Center with seven villages working area, five Pustu and one is Lumut Maju village. Lumut Maju Village is a direct border village with Batang Toru (South Tapanuli) and the villagers live on the banks of streams, swamps, oil palm plantations and find it difficult to access health services. The number of the inhabitants of the village of Moss developed as much 1,200 people and the majority are Nias people $(97 \%)$ with livelihoods as farmers or oil palm plantation workers who are close to the village (Lumut Public Health Center Profile, 2017).

\section{Review of Literature}

\subsection{Filariasis (Elephantiasis Disease Disease)}

Filariasis or so-called elephantiasis is a chronic infectious disease caused by filarial worm infection, which lives in the ducts and lymph nodes (lymphatic system) and can cause acute and/or chronic clinical symptoms. These worms cause infections in humans by being transmitted by mosquito vectors (Permenkes RI, 2014).

Filarious worms that resemble threads with Wuchereria bancrofti and Brugia malayi types cause lymphatic filariasis that lives in humans. This worm lives in the lymphatic system, which is a network consisting of glands and lymph vessels that functions to maintain fluid balance between body tissue and blood and is an important component in the human body's defense system. Filarious parasites live for four to six years, and produce millions of immature microfilariae that circulate in the blood (WHO, 2012).

Permenkes No. 94 of 2015, explained that filariasis in Indonesia is caused by three species of filarial worms, namely: Wuchereria bancrofti, Brugia malayi and Brugia timori. And in epidemiology filarious worms are divided into 6 types, namely: (a). Wuchereria bancrofti urban type; Found in urban areas such as Jakarta, Bekasi, Tangerang, Semarang, Pekalongan and surrounding areas. Having a nocturnal periodicity and transmitted by Culex quinquefasciatus mosquitoes that breed in domestic wastewater, (b). Wuchereria bancrofti rural type; Found in rural areas outside Java, especially widespread in Papua and East Nusa Tenggara. Has a nocturnal periodicity and is transmitted by various Anopheles mosquito species. (c). Brugia malayi nocturnal periodic type; Microfilariae are found in the peripheral blood at night and are transmitted by Anopheles barbirostis mosquitoes found in rice fields. (d). 
Brugia malayi type nocturnal sub periodic; Microfilariae are found in the peripheral blood at day and night, but more are found at night. Infectious mosquitoes are Mansonia sp found in swampy areas (e). Brugia malayi non periodic type; Microfilariae are found in peripheral blood both at night and during the day. Infectious mosquitoes are Mansonia bonneae and Mansonia uniformis found in the jungle. (f). Brugia malayi type nocturnal periodic brugia; Microfilariae are found in the peripheral blood at night. The infectious mosquito is Anopheles barbirostis which is found in rice fields in East Nusa Tenggara and Southeast Maluku (Appendix Permenkes No. 94, 2014).

\subsection{Morphology of Filaria worms}

In general, the life cycle of the three filaria worm species is no different. Parasite life cycle occurs in the human body and mosquito body. Adult worms (called macrophilaria) live in the glands and lymph nodes, while their offspring (called microfilaria) are present in the circulatory system. Microfilariae can be found in the peripheral blood at certain times according to periodicity, in general nocturnal periodicity, which is found in the peripheral blood at night, while during the day there are many in the capillaries of internal organs such as the lungs, heart and kidneys (Febiger, 2013).

\subsection{Macrophilaria}

Macrophilaria (adult worms) are cylindrical, smooth like milky white threads and live in the lymph system. Female worms are ovoviviparous and measuring $55-100 \mathrm{~mm} \times 0.16 \mu \mathrm{m}$, can produce millions of microfilariae. Male worms are smaller $\pm 55 \mu \mathrm{m}$ x $0.09 \mathrm{~mm}$ with a circular tail tip. Macrophilaria can survive long enough in the lymph glands, and can damage the lymph system where the worm lives. Macrophilaria will die by itself after 5-7 years, but severe lymphatic system damage cannot be recovered (Permenkes RI, 2014).

\section{Three Filarial Worms}

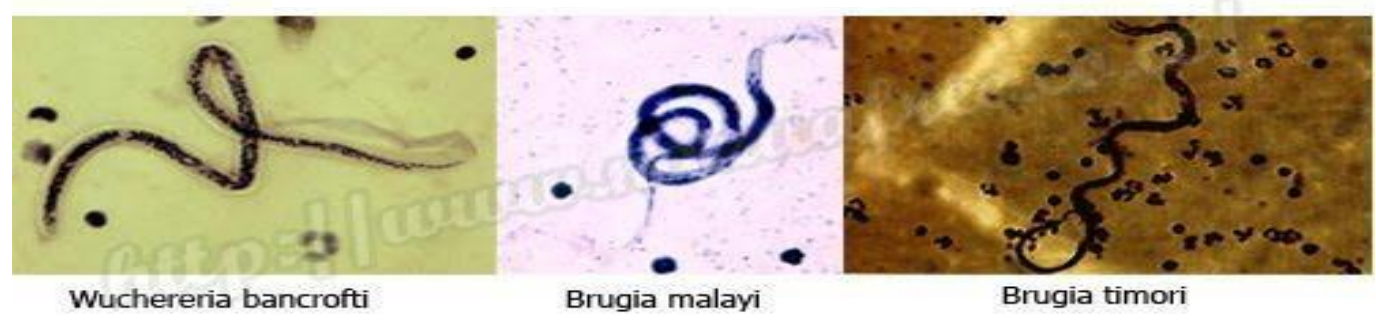

Figure 1. Macrophilariae (adult filaria), source of Permenkes No 94, 2014

\section{Research Methods}

This research is a qualitative type of research with domain analysis. Domain analysis is the first step in conducting qualitative research with the aim to describe the general and overall description of the object of research in this case is the determinant of the incidence and filariasis prevention in Lumut Maju Village, Lumut Sub-district, Central Tapanuli Regency.

The study was conducted in Lumut Maju Village, Lumut Sub-district, Central Tapanuli Regency and work units related to the research problem. The basis for selecting the location of this study was the consideration that research had never been conducted related to the problem of incidents and filariasis prevention in Central Tapanuli Regency and from the results of examinations by health workers in the district of Tapanuli Tengah and the North Sumatra Provincial Health Office that Central Tapanuli was the third highest ranking filariasis cases with 22 cases (Profile of Provincial Health Office, 2017). 


\section{Discussion}

Filariasis prevention in this study in Central Tapanuli Regency especially filariasis endemic areas namely Lumut Maju Village are stipulated in accordance with the Decree of the Minister of Health Number 94 of 2014, including: (1) Regulation; (2) Health services through; (a) Treatment of sufferers; (b) Control of risk factors; (c) Communication, information and education provided to the community to achieve the objectives of Indonesia's elimination of elephantiasis in 2020.

The informants relating to the implementation of the filariasis countermeasure program in this study numbered five people, including: one person, Head of P2P Department of Health, Central Tapanuli; one of Lumut Maju Health Center Head; one of DPRD Commission A Central Tapanuli, one of Lumut Sub-District Head and one of Lumut Maju Village Head. The implementation of determinants of filariasis prevention in Lumut Maju Village can be seen based on the following data;

\subsection{Regulation}

The stipulation of the regulation regarding filariasis in question is the stipulation of the Regent's Decree as a PERDA (Regional Regulation) with the aim of determining the funds to be used in carrying out the filariasis countermeasure program and the filariasis countermeasure control program which is carried out through health services or across sectors according to the explanation in Permenkes No. 94 of 2014. The regulations are established with the main objective being accelerate the implementation of the response to filariasis to achieve Indonesia elimination of filariasis in 2020.

The results of interviews with local government officials related to the establishment of regulations in the implementation of filariasis prevention in Lumut Maju village, Central Tapanuli Regency are as follows;

"Saya tahu ada penderita positif filariasis di daerah kerja saya pada bula juli tahun 2017, ada laporan dari puskesmas batang toru yang merupakan fasilitas kesehatan tapanuli selatan menyatakan bahwa ada beberapa masyarakat tapanuli tengah datang berobat dengan kondisi demam dan keluhan kaki membengkak. Berdasarkan hal tersebut kami meninjau lapangan dan memang benar bahwa ada masyarakat yang mengalami kaki bengkak setelah melakukan pemeriksaan fisik maka kami membuat laporan ke Dinas Kesehatan Tapanuli Tengah untuk di teruskan ke Dinas Kesehatan Provinsi Sumatera Utara.

Sampai saat ini belum ada peraturan apa-apa secara tertulis dari dinas kesehatan apalagi yang sudah ditetapkan sebagai peraturan daerah patinya tidak ada. Dasar kami melakukan program penanggulang filariasis pertama sekali adalah karena kami meresa bertanggungjawab dan pelaksanaannya tetap kami mengarah pada permenkes No 94 tahun 2014," (Kepala Puskesmas Lumut Maju).

"Kami mengetahui tentang semua masalah kesehatan di derah ini berdasarkan laporan dari Fasilitas Kesehatan, dalam hal ini kami mendapatkan laporan dari Puskesmas Lumut Maju. Setelah kami mendapatkan laporan kemudian kami turun langsung kelapangan berkoordinasi dengan pejabat desa untuk mengumpulkan masyarakat kemudia kami lakukan observasi dan pemeriksaan fisik, dari hasil tersebut memang ada beberapa dari masyarakat yang mengalami tanda-tanda menderita filariasis. Hasil tersebut menjadi dasar kami melaporkan kepada Dinas Kesehatan provinsi supaya melakukan survei langsung. Tidak ada peraturan berupa regulasi tentang penanggulangan penyakit menularjadi sampai saat ini kita hanya melaksanakan program penanggulangan sesuai dengan Permenkes saja dan itu sudah 
dikerjkan oleh puskesmas lumut," (Kabid P2M Dinkes Tapteng).

"Saya mulai dengar tentang adanya penyakit kaki gajah dan ada yang menderita tersebut di kecamatan ini, sewaktu rapat koordinasi akhir tahun 2017, Kemudian disitulah pak dokter (Kepala Puskesmas) menyampaikan bahwa ada penyakit yang sedemikian rupa yang diderita oleh masyarakat lumut maju yang notabene merupakan wilayah kerja yang saya pimpin, tidak ada peraturan yang ada tentang penanggulangan penyakit di kecamatan" (Camat Lumut).

Based on the results of the interview above which involved the Head of Lumut Health Center, Head of P2M Central Tapanuli Health Office and Lumut Sub-District Head about the presence/absence of regulations relating to the prevention of filariasis, that the local government (DHO) has taken action to ensure information by engaging directly in and checking related information obtained from people who experience symptoms of elephantiasis.

Specific regulations regarding the prevention of filariasis towards Indonesia elimination of filariasis 2020 in Central Tapanuli Regency have not yet been established. This is known through an explanation given by the Head of P2M and the Head of the Public health center who directly involved in handling the problem. Explanation of Head of P2M emphasized that many health problems that occur are even worse than filariasis, but until now there have been no regulations that regulate their handling. Therefore, what has been done so far is a collaboration of filariasis prevention activities from the health department with the Public health center using existing funds.

The results of the interview relating to the basis for establishing regulations (provision of rights, obligations, sanctions, funds and program control) in implementing filariasis prevention were obtained:

"Tidak ada regulasi kami hanya melakukan pengobatan dan tindakan pencegahan melalui memberi obat pada pasien dan pada masyarakat di daerah tersebut, kalau dana kami kelola dari dana kunjungan yang sudah direncanakan dan untuk pengobatan diambil dari ketersediaan obat di farmasi, kami sedikit kesulitan karena tahun lalu tidak ditemukan penderita di daerah tersebut dengan jumlah yang dapat dikatakan banyak sehingga menyita perhatian lebih. Untuk penanganan di lapangan secara intensif berkelanjutan kami serahkan pada puskesmas yang memiliki wilayah kerja," (Kabid P2M Dinkes Tapteng).

"Tidak ada peraturan atau sanksi terhadap pelaksanaan program penanganan atau penanggulangan filariasis, dana yang kami gunakan adalah dari dana BOK dan dana yang tersedia sebagai biaya transportasi dan biaya kunjungan tenaga kesehatan karena kalau ke daerah tersebut membutuhkan waktu dan biaya yang cukup banyak. Kami melakukan pengobatan dan penyuluhan pada penderita begitu juga kepada masyarakat secara umum, pemberian obat pencegahan tetap kami lakukan bagi yang belum terdata mendapatkan obat pencegahan penyebaran filariasis sebelumnya," (Kepala Puskesmas Lumut).

"Dalam membuat regulasi kebijakan behubungan dengan kesehatan public memang yang harus metetapkan adalah pihak kami, untuk yang berkaitan dengan penyakit menular filariasis atau kaki gajah saya tidak pernah tahu, dari dinas kesehatan sendiri belum pernah mengusulkan regulasi yang dimuksud dan belum ada wacana pembahasan terkait regulasi tersubut. Sebenarnya kalau memang sudah ada draf tentang regulasi itu kita akan tampung dan kita tindak lanjuti, lagian kebijakan itu juga penting untuk mengatur tatacara dan penganggaran dalam membasmi dan menanggulangi penyakit kaki jagah," (DPRD Komisi A). 
The results of interviews with representatives of local governments represented by the Head of P2M Health Office Central Tapanuli Regency, Head of Health Center of Lumut Subdistrict and DPRD Commission A in the field of health can be concluded, that there are no sanctions against health workers or health facilities if they do not carry out a filariasis prevention program because basically sanctions and rules are stipulated in a single regulation (regulation or SK) made. The health office provides medicines needed for the implementation of the filariasis prevention program, but funds for conducting visits or other activities come from operational funds in the filariasis endemic health service unit.

In the context of filariasis prevention, the Regency / city regional government is responsible for: Carrying out filariasis prevention, coordinating and networking with relevant local government work units and conducting partnerships with non-governmental organizations and academics relevant to filariasis prevention, monitoring and evaluating filariasis prevention in the technical implementation unit and / or in the community, conducts technical guidance for filariasis prevention in the technical implementation unit, conducts technical training for filariasis prevention for technical and community implementation units (Permenkes, 2014).

Interview results related to the implementation of the POPM Filariasis and Elephantiasis Disease Elimination Month memorial activities in Lumut Maju village:

"Pada penderita pertama sekali dilakukan pemeriksaan fisik kemudian dilakukan pemeriksaan darah jari. Kemudian pemberian obat pencegahan untuk menghentikan aktivitas larva cacing kepada penderita yang sudah positif filariasis. Pelaksanaan POPM Filariasis hanya dilakukan pada tahun pertama itu, selanjutnya memang kami serahkan kepada puskemas. Kalau mereka (puskesmas) minta obat ya kita kasih karena ada obat di farmasi jadi tinggal amprah saja" (Kabid P2M Dinkes Tapteng).

"Setelah pemerikasaan darah yang melibatkan dinas kesehatan provinsi dan pemberian obat terhadap penderita, kami memberikan obat bagi masyarakat. POPM Filariasis kami lakukan setiap kunjungan, memang tidak sekaligus karena sulit sekali mengumpulkan masyarakat secara bersama begitu juga waktu kunjungan kami yang tidak teratur karena tergantung cuaca dan dana. Untuk program peringatan BELKAGA, tidak ada kami lakukan apa-apa karena musim penghujan saat itu, kurang maksimallah kalau pelayanan di lumut maju ini,banyak tergantungnya...tergantung dana, tergantung cuaca, tergantung kerjaan dipuskesmas karena kalau kesana ga bisa ga rame-rame"(Kepala Puskesmas Lumut).

"Bapak dokter sering mengingatkan kami..data yang belum dapat obat, data yang tidak pernah datang kalau dibuka pelayanan kesehatan, POPM Filariasis, saya tidak tahu itu bu...tapi kalau orang pak dokter datang selalu nya memang bawa obat. Tidak ada kegiatan khusus untuk penyakit kaki gajah disini,,belum pernah dibuat oleh orang pak dokter itu bu. Tak ada penanggulangan yang kami lakukan untuk penyakit ini,,karena kalau kami yang menyampaikan masyarakat ini tidak percaya,,disuruh saja ngumpul ga ada yang datang"(Kelapa Desa Lumut Maju).

The results of the above interview can be concluded, that the POPM Filariasis was not conducted as it should and the Elephantiasis Disease Elimination Month warning program was not carried out in Lumut Maju Village. POPM Filariasis activities are carried out once a year in a row for at least five years after a finger blood examination is performed.

POPM Filariasis activities are carried out for all residents aged two years to 70 years in the endemic area of filariasis. The drugs given are Diethyl Carbamazine Citrate (DEC), 
Albendazole, and drugs used for subsequent events after administration of preventive drugs for filariasis (paracetamol, CTM, doem antacids, amoxicillin, oral antibiotics, Vitamin B6 etc.).

Efforts as a strategy that can be done by local governments in cooperation with crosssectorial breaking of the chain of filariasis transmission by administering mass prevention drugs (POMP) of filariasis in the regions the endemic (Dwilaya, 2013).

The profile of the North Sumatra Provincial Health Office (2016) shows that Central Tapanuli Regency is the 3rd most cases of filariasis from the total districts / cities in North Sumatra Province with a total of 15 cases of filariasis. From the foregoing the local government should have special attention and have enthusiasm in planning, contributing and carrying out mitigation and planning regulations or policies related to the treatment of filariasis.

Lumut Maju Village which is a filariasis endemic area, cross-sectoral government cooperation in order to break the chain of filariasis transmission is needed. The intended cooperation gives special attention to the development of the community in the village so as not to become an isolated community. Planning village development through the construction of roads, electricity and water supply is a form of support for community growth and development towards better health. Determination of regulations and availability of funds in the prevention activities program is also an important factor in achieving the elimination of filariasis 2020 .

\subsection{Health Services}

The role of health services of the filariasis prevention is through the management of filariasis sufferers, the control of risk factors, the existence of communication, information and education to the public both who have contracted filariasis and those who are at high risk of contracting the disease in Lumut Maju Village, Lumut Sub-district, Central Tapanuli Regency.

The results of interviews related to the implementation of basic health services, especially those related to infectious diseases filariasis in Health Center of Lumut Sub-district get:

"Untuk pelayanan kesehatan tingkat dasar di puskesmas kita ini emang sudah berjalan lama, sejak didirikanya puskesmas ini.Tapi untuk kegitan pelayanan dan penanggulangan filariasis ya tergantung dari dinas kabupaten. Kalau dinas kabupatennya mengintruksikan kepada puskesmas, ya kita jalankan," (Kepala Puskesmas Lumut).

"Pelayanan kesehatan di Puskesmas Kecamatan Lumut sudah jalan dari pertama kali puskesmasnya berdiri. Untuk pelayanan dan penanggulangan terkait penyakit menular filariasis atau penyakit kaki gajah, mereka akan melaksanakan apabila ada intruksi dari dinas kesehatan atau dari pihak kami. Seperti kejadian pada tahun 2017 silam adanya kasus yang di curigai penyakit kaki gajah pada masyarakat Desa Lumut Maju yang di informasikan oleh masyarakat. Selanjutnya kami dari pihak dinas menyarankan agar petugas dari puskesmas untuk memeriksa masyarakat yang dicurigai mengalami penyakit kaki gajah,"(Kabid P2M Dinkes Tapteng).

"Di Kecamatan kami ada puskesmas, otomatis pelayanan pasti dilakukan oleh petugas disana. Tapi untuk pemeriksaan dan pengobatan penyakit kaki gajah warga kami jarang dilakukan berhungan dengan jarak yang lumayan jauh, apabila masyarakat desa kami yang menderita, demam, bengkak di kaki, mereka tidak membawanya ke puskesmas karna puskesmasnya terlalu jauh. Biasanya masyarakat kita disini membawa 
keluarganya yang sakit ketempat orang pinter atau dukun,atau membeli obat nyeri di toko obat," (Kepala Desa Lumut Maju).

"Biasanya pak dokter (kepala Puskesmas) langsung memberitahu kepada kami pihak kecamatan apabila terjadi suatu penyakit pada masyarakat yang dianggap penting penanganannya. Pelayanan puskesmas ini memang kami lihat sudah maksimal tapi karena daerah lumut ini sangat luas dan khususnya desa lumut maju itu sangat jauh sekali sehingga sulit untuk melakukan kunjungan yang rutin. Semua tergantung pada cuaca... walau demikian dari laporan pihak puskesmas setiap 3 bulan rapat koordinasi menyatakan bahwa selalu ada usaha yang dilakukan untuk menjangkau masyarakat lumut maju dengan tujuan meningkatkan derajat kesehatan masyarakat disana" (Camat Lumut).

All information obtained from the interview results above can be obtained concluded, that there are no regulations governing filariasis prevention. The basic level of health services namely Health Center of Lumut Sub-district conducts Elephantiasis Disease prevention activities in accordance with the provisions of the Minister of Health, but not optimal because the distance and cost required is large enough to conduct each visit. In the treatment of patients with filariasis directly carried out only once in Lumut Maju Village by involving the provincial health office, Regency health office and health centers that is when the finger blood survey. Then the next activity is submitted to the Public health center facilities to conduct routine monitoring of patients with filariasis. However, the long distance and travel time resulted in filariasis prevention activities, especially visits and treatment from Public health center which was hampered and not routine.

\section{Conclusion}

In the context of filariasis prevention, the local government has not coordinated and established networks with relevant SKPDs and in partnership with relevant NGOs and academics. Handling of patients that aims to prevent and limit disability by providing care training to patients and families has not been done to the maximum. Control of risk factors does not work well because the patient is not maximally netted. The eradication of infective mosquitoes by minimizing mosquito nesting through environmental management (swamps, watersheds, and puddles with water plants) with mutual assistance activities and community empowerment has not been done.

\section{References}

Anshari, R. (2014). Analisis faktor risiko kejadian filariasis di Dusun Tanjung Bayur Desa Sungai Asam Kecamatan Sungai Raya Kabupaten Pontianak (Tesis, Universitas Diponegoro Semarang). Diakses dari http://media.neliti.com/media/publications/4855-ID-analisis-faktor-risiko- kejadianfiliarisis-dusun-tanjung-bayur-desa-sungai-as.pdf.

Balai Teknik Kesehatan Lingkungan dan Pengendalian Penyakit (BTKLPP) Kelas I Makassar. (2013). Kajian surveilans epidemiologi filariasis (survei darah jari) di Puskesmas Wuna, Kabupaten Muna Provinsi Sulawesi Tenggara. Makassar. Bain, O., \& Babayan, S. (2013). Behaviour of filariae: Morphological and anatomical signatures of their life style within the arthropod and vertebrate hosts. Filaria Journal, 2(1), 16.

Buku Saku Dokter. (2013). Filariasis dan penanggulangan. Diakses pada 14 Maret 2018 dari http://bukusakudokter.Org.

BPOM RI. (2015). Canangkan belkaga untuk Indonesia sehat dan bebas kaki gajah. Diakses pada 11 April 2018 dari https://www.pom.go.id/. 
Candra, B. (2013). Kontrol penyakit menular pada manusia (buku kedokteran). Jakarta : EGC.

Center for Disease Control and Prevention. (2014). Lymphatic filariasis (online) (cited 2014 Oct 2014, 12 screens). Diakses dari www. cdc.gov/ parasites/ lymphatic filariasis.

Chesnais, C.B., Missamou, F., Pion, S.D., Bopda, J., Louya, F., Majewski, A.C., Fischer, P.U., Weil, G.J., \& Boussinesq, M., (2014). A case study of risk factors for lymphatic filariasis in the republic of congo. Parasites \& Vectors, (7)5, 300.

Creswell, J. (2017). Research design metode pendekatan kualitatif, kuantitatif dan campuran. Yogyakarta: Pustaka Pelajar.

Dinas Kesehatan Tapanuli Tengah. (2017). Profil Dinas Kesehatan. Diakses dari Profil Dinas Kesehatan Provinsi Sumatera Utara. Dinas Kesehatan Provinsi Sumatera Utara. (2017). Profil Dinas Kesehatan Provinsi Sumatera Utara. Diakses dari http://www.depkes.go.id/resources/ downloads/profil_kes_provinsi_2017/02_Sumut_2017.pdf.

Ditjen PP\&PL Depkes RI. (2009). Pedoman Program Eliminasi Filariasis di Indonesia. Daiseks dari http://www.depkes.go.id/resources/download/ pusdatin/ profilkesehatan-indonesia/profil- kesehatan- indonesia.2009.pdf

Faisal, S. (1999). Format-format penelitian sosial. Jakarta : PT Raja Grafindo Persada.

Irianto, K. (2014). Epidemiologi Penyakit Menular \& Tidak Menular (panduan teknis). Bandung: Penerbit Alfabeta.

Infodatin Kemkes. (2016a). Filariasis dan Program Belkaga. Diakses tanggal 12 Mei 2018 dari http://www.kemkes.go.id.

Infodatin Kemkes. (2016b). Situasi Filariasis di Indonesia Tahun 2015. Diakses tanggal 03 Juni 2018 dari http://www. kemkes.go.id.

Kusuma, D. (2011). Metode penelitian sosial. Bandung : Pustaka Setia. Kurniasih, N. (2009). Buku ajar ilmu penyakit dalam. Jakarta : Interna Publising.

Maryen,Y. (2014). Faktor Risiko yang berhubungan dengan kejadian filariasis di Kabupaten Manokwari Provinsi Papua (Tesis Fakultas Kedokteran Universitas Gajah Mada). Diakses dari http://lib.ugm.ac.id/ind/? page_id=248.

Peraturan Menteri Kesehatan Republik Indonesia No 94 Tahun 2014 tentang Penanggulangan Filariasis.

Sugiyono. (2017). Metode penelitian kualitatif. Bandung : Alfabeta.

Sanyoto, D. (2011). Analisis penelitian kesehatan. Yogyakarta : Nuha Medika. Spradley, J. P. (2007). Metode etnografi. Yogyakarta : Tiara Wacana.

Santoso., Yenni, A., \& Mayasari, R. (2010). Faktor risiko kejadian penyakit filariasis pada masyarakat di Indonesia. Buletin Spirakel. Loka Litbang P2B2 Baturaja. ISSN 20861346.

Saniambara, N. (2015). Filariasis dan beberapa faktor yang berhubungan dengan penularannya di Kecamatan Rotu Timur Kabupaten Rotu Ndao Provinsi Nusa Tenggara Timur (Tesis, Fakultas Kedokteran, Universitas Gadjah Mada). Diakses dari http://lib.ugm.ac.id/ind/? page_id $=248$

Uloli, R. (2007). Analisis faktor-faktor kejadian filariasis di Kabupaten Bone Belango Gorontalo (Tesis, Fakultas Kedokteran Universitas Gajah Mada). Diakess dari

World Health Organitation. (2016). Lympatic Filariasis: Monitoring and Epidemiological Assessment of mass Drug Administration. France: World Health Organitation. Diakses dari http://www.who.int/medicentre/filiarisis/en/2016.

Pongsuk, P. \& Chaikitmongkol, S. (2006). Evaluation of public relation and behavioral responses to prevention and control measures against lymphatic filariasis afficting people living in epidemic areas in Thailand. Philippine Journal of Science, 135(2), 31137. 